\title{
Incompatibility of sulphate compounds and soluble bicarbonate salts in the Rio Cruces: reply to Harding et al. (2007)
}

\author{
Sandor Mulsow ${ }^{1,2, *}$, Mariano Grandjean ${ }^{1}$
}

${ }^{1}$ Instituto de Geociencias, and ${ }^{2}$ Forest Ecosystem Services Research (FORECOS), Universidad Austral de Chile, Casilla 567 - Valdivia, Chile

Regarding the fate of Egeria densa in the Rio Cruces estuary, we consider that no new data has been put forward by Harding et al. (2007, available at: www.int-res.com/articles/esep/2007/E72.pdf) on the real issue of the Ramsar site, Carlos Andwandter Sanctuary, its collapse. However, we answer the criticisms raised by Harding et al. (2007) below.

The major contribution to the issue by Harding et al. (2007) is their statement: 'This does not preclude the possibility that effluent from the CELCO pulp mill may have caused adverse effects in the sanctuary.'

Harding et al. (2007) propose that potassium may have caused the effect observed in the microcosm experiments of Mulsow \& Grandjean (2006). This possibility will be tested and published in due course under similar but more precise measurements of the photorespiration of Egeria densa if funds are available.

The arguments of Harding et al. (2007) with respect to the field data of Mulsow \& Grandjean (2006) neglect the fact that we are working in a complex aquatic environment, in which residence time and hydraulic and tidal regimes dominate the scenario where all the reactions take place. Mulsow \& Grandjean (2006) mentioned that $\mathrm{pH}$ and temperature are also major contributors to anion-cation exchange conditions and dominance of $\mathrm{CO}_{2}$ or $\mathrm{HCO}_{3}$ in the water.

Editorial responsibility: Susan Mooney,

Easton, Massachusetts, USA
Harding et al. (2007) fail to comment on the historical evidence of change in $\mathrm{HCO}_{3}$ at Rucaco station (DGA [1993], Station Code 10134800-8). Before the pulp mill began producing cellulose, Rucaco station, approximately $1 \mathrm{~km}$ downstream from the pulp mill, had 0.6 $\mathrm{mg} \mathrm{l}^{-1}$ of sulphate, compared to present values of more than $4 \mathrm{mg} \mathrm{l}^{-1}$. We insist that this is not a coincidence: this is not a river, it is a sanctuary located in an estuary; this is not distilled water chemistry, a deep water body, or a simple ecosystem.

If the discharge water is as clean as the pulp mill says it is, then why don't they discharge it upstream of the water intake supplying the cellulose plant? This would decrease the impact, if any, to a minimum, with no need to discharge to the nearby sea.

\section{LITERATURE CITED}

DGA (Direccion General de Aguas de Chile) (1993) Diagnostico y Clasificacion de los cursos y cuerpos de agua segun objetivo de calidad: Cuenca Rio Valdivia. DGA, Ministerio de Obras Publicas, Santiago

Harding L, Pretorius J, McGurk M (2007) Recent changes in the Rio Cruces: Comment on Mulsow \& Grandjean (2006). ESEP 2007:1-3

Submitted: December 15, 2006; Accepted: December 26, 2006 Proofs received from author(s): March 21, 2007 